\title{
THE PERSPECTIVE OF ISLAMIC EDUCATION TO EDUCATIONAL METHODS
}

\author{
Andi Achruh 1 , Muhammad Rusydi Rasyid ${ }^{2}$, Nursalam ${ }^{3}$, M. Shabir U. ${ }^{4}$ \\ 1,2,3,4Universitas Islam Negeri Alauddin Makassar, Fakultas Tarbiyah dan Keguruan \\ 1,2,3,4 Jalan H. M. Yasin Limpo No. 36 Samata-Gowa \\ Email: andi.achruh@uin-alauddin.ac.id ${ }^{1}$, muhammad.rusydi@uin-alauddin.ac.id², \\ nursalam_ftk@uin-alauddin.ac.id³ , mshabiru@uin-alauddin.ac.id4
}

\begin{abstract}
:
Islamic education is a system consisting of several important components that are interconnected. Among the existing components is the method of education. This study aimed to determine the learning methods used in Islamic education. This research used library research with a qualitative approach. Data sources were derived from various works of literature, including books, articles, newspapers, and documents. The data analysis techniques used were content and descriptive analyses. The finding indicated that several teaching methods used in Islamic education, including; 1) Lecture method, 2) Discussion method, 3) Demonstration method, 4) Insertion method, 5) Wrapping method, and 6) Inquiry method. Therefore, teachers are required to choose and determine the right method so that the achievement of educational goals can be carried out effectively and efficiently.
\end{abstract}

\begin{abstract}
Abstrak:
Pendidikan Islam merupakan suatu sistem yang terdiri dari beberapa komponen penting yang saling berhubungan. Diantara komponen yang ada adalah metode pendidikan. Penelitian ini bertujuan untuk mengetahui metode pembelajaran yang digunakan dalam pendidikan Islam. Penelitian ini menggunakan penelitian kepustakaan dengan pendekatan kualitatif. Sumber data berasal dari berbagai karya kepustakaan, antara lain buku, artikel, surat kabar, dan dokumen. Teknik analisis data yang digunakan adalah analisis isi dan deskriptif. Hasil penelitian menunjukkan bahwa beberapa metode pengajaran yang digunakan dalam pendidikan Islam antara lain: 1) Metode Ceramah, 2) Metode Diskusi, 3) Metode Demonstrasi, 4) Metode Sisipan, 5) Metode Bungkus, dan 6) Metode Inquiry. Oleh karena itu, guru dituntut untuk memilih dan menentukan metode yang tepat agar pencapaian tujuan pendidikan dapat terlaksana secara efektif dan efisien.
\end{abstract}

Keywords:

Islamic Education, Perspective, Educational Method

How to Cite: Achruh, A., Rasyid, M. R., Nursalam, \& Shabir, M. (2021). The Perspective of Islamic Education to Educational Methods. Lentera Pendidikan :Jurnal Ilmu Tarbiyah dan Keguruan, 24(1), 114-121. https://doi.org/10.24252/lp.2021v24n1i11.

\section{INTRODUCTION}

Education is a physical, mental, and moral exercise for individuals to become cultured human beings and have social personalities. Hence, they can fulfil their duties as humans and become useful. This idea has been believed by most of the leading educational scholars of all time. For example, John Dewey in Khursyid Ahmad stated that 
education is a process of forming fundamental skills, intellectually and emotionally, towards the realm of fellow human beings (Ahmad, 1958: 9). Islam is comprehensive and integrated teaching which regulates all aspects of human life, both life matters of the world and hereafter. At the same time, education is an inseparable part of Islamic teachings, an integrated part of Islamic teachings (Nasution, 2001: 153).

Allah is the main source of education for every Muslim. He gives knowledge and teaching to humankind by revelation to His messengers. The Prophet Muhammad educated and taught humans based on the ideals and principles of God's teachings, engaged and prepared Muslims to uphold justice and prosperity in order to create a society that Allah blesses. Thus, Islamic education inspires the younger generation to have a deep recognition of Islamic philosophy and ideology both as individuals and as members of society (Afzalurrahman, 1980: 367-368).

The basis of Islamic education is identical to the basic teachings of Islam. Both come from the same source, namely Al-Qur'an and Al-Hadith. Then, the foundation is developed into ijma that is approved, ijtihad and correct interpretation in the form of comprehensive and integrated thinking about the universe, human beings, society and nation, human's knowledge and morals, which refer to both sources (al-Qur'an and alHadith) as the main sources (Al-Syaibani, 1979: 43). Al-Quran and Al-Hadith as the basis of thought in the educational system are not only seen as truth based on belief alone. Further, the truth can also be accepted by reason.

Learning is a window to the world because, by learning, people can know many things. Therefore, Islam places great emphasis on learning problems. Allah also asked in QS. Al-Zumar 39: 9 (Ministry of Religion of the Republic of Indonesia, 1997: 891) as follow:

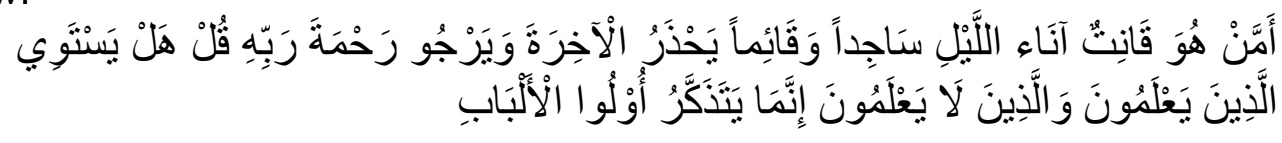

(9) Is the one who is obedient (to Allah, worships Allah devoutly) during hours of the night, prostrating himself and standing, fearing the hereafter, and hoping for the Mercy of Allah? Say: "Are those who know and those who do not know ever equal? Only the ûli'l elbâb (the owners of the continuous remembrance, the owners of the secret divine treasures) understand."

The answer to that verse can be found in QS. Al-Mujadalah/58: 11 (Ministry of Religion of the Republic of Indonesia, 1997: 325) as follow:

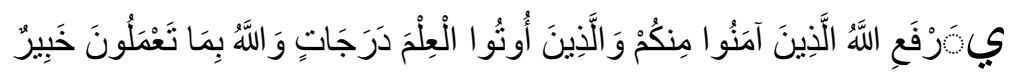

(11) 0 you who believe (who are âmenû)! When it is said to you in assemblies: "Make room (for others to sit)", then make room. Allah will also give you (ample) room. And when it is said: "Rise up!", then rise up immediately. Allah increases the degrees of those of you who believe (who are âmenû, who wish to reach Allah before death), and given knowledge. And Allah is All-Aware of what you do.

The Prophet Muhammad strongly encouraged learning by giving practical examples in words and actions. He had freed the learned infidels' prisoners if they could teach some Muslims to read and write. It was a sign that he strongly desired education to 
be evenly distributed among Muslims (Al-Abrasyi, 1992: 8).

Regarding the scope of Islamic education, it can be seen in the classification of the meaning of Islam in general. Scholars generally divide Islam into three aspects, namely God, human, and nature. In Islamic learning, this division is included as the scope of Islamic Education, which is taught in public schools as insight about Aqidah (divinity), humans, and nature (social mualah) (Daud, 2006: 49).

Islamic education is a system that is involved in various interrelated components. The method of education is one of the system's main components. The study of educational methods is indeed a matter of discussion that remains actual and interesting because this also determines the success or failure of the educational process in achieving educational goals. For this reason, educational methods must be developed dynamically according to the needs and demands of the times.

Islamic educational methods differ from those of other educational systems. Thus, developing the desired educational method within the Islamic educational system must be consistent with Islamic education's characteristics. Educational methods, in particular, those implementing Islamic education, must be developed. If the educational method used to remain classical, static, and monotonous for students, it would have a detrimental effect on Muslims' quality of life, which will continue to deteriorate. Indeed, there is a tendency for Islamic education's dynamics at the implementation level to be less competitive with those of other educational institutions. Many factors certainly influence it. One of them is the weak development of the educational method itself.

In the process of Islamic education, approaches and methods play a vital role in achieving objectives. Even through approaches and methods that are considered to be art, it is possible to transfer knowledge/subject matter to students that are considered more important than the material itself. As a result, appropriate methods have a significant impact on achieving success during the teaching and learning process. Inappropriate approaches and methods result in inefficient time management (Rianie, 2015).

Additionally, the methods must be accurate and appropriate for the character and type of the subject to be delivered not to obstruct the teaching and learning process. Thus, teachers' methods can be successful if the desired outcomes can be achieved using these methods (Mahmud \& Priatna, 2008: 160).

According to Fikri (2011) one of the challenges in educational institutions is that teachers pay less attention to classroom delivery methods, even when certain methods are already considered extremely classic still implemented and maintained. On the other hand, students need effective and practical learning methods to efficiently, precisely, and readily comprehend the lesson. The students need a professional and appropriate teaching figure to carry out their responsibilities competently and effectively. Interestingly, this issue arises more frequently in Islamic educational institutions that have long been labelled conservative and even appear to be classic. 
Educational success will only be achieved if all components of education fulfil their duties and obligations appropriately. As one of the important components in education, Islamic educational methods should focus on innovative learning methods which will accelerate educational success. This study described specifically related to the various types of methods used in the context of Islamic education.

\section{RESEARCH METHOD}

This research used library research with a qualitative approach. It is a series of activities related to collecting library data, reading and taking notes and processing research materials. Data sources were derived from various works of literature, including books, articles, newspapers, documents, and others. The data analysis techniques used were content and descriptive analyses. Content analysis or content study is a research methodology that utilizes a set of procedures to draw valid conclusions from a book or document. The data analysis technique in the form of content analysis was used in this study because of library research. The data sources were books, articles, documents, and works of literature. At the same time, the descriptive analysis was used to describe the content. By using these two together, it is expected to provide maximum meaning interpretation of the data.

\section{RESULTS AND DISCUSSION}

\section{Method of Islamic Education}

The method has several definitions. It means to implement (Kurniawan, 1997: 270). The term "method" also is defined as doing something in an object (Salim, 1999: 9). The method is described as a general scientific, concerned with types, characteristics, rules, and standards for action and agreement (Amir, 2002; Muhajir, 1998). The method comes from two words, namely "metha" and "hodos." "Metha" means "through or by," and "hodos" means "way." Thus, a method is a path or way that must be followed to achieve a goal (Arifin, 1994: 61). Educational methods are all the ways used to educate. The word "method" is broadly defined because teaching is a form of educational effort. The method referred to in this research includes teaching methods (Soetoe, 1982: 28).

According to Basyiruddin (2007: 19), a method is a way of instilling knowledge to someone in a concise and definite manner. In other words, a method can be interpreted as a science that talks about principles in delivering learning material so that it can be mastered or owned by students who receive it. Therefore, according to the authors, the method is closely related to the learning process. Methods can be interpreted as well thought to achieve goals or objectives or a systemized way to achieve specified goals (Ministry of Education and Culture of Republic of Indonesia, 1990: 580). The educational method is the same as methodology, which discusses the way (how) or technique to present learning material to students to achieve a predetermined goal effectively and efficiently (Usman, 2007: 4).

The definition of educational methods is an orderly and thoughtful way to achieve educational goals or objectives (Uhbiyati, 2008: 123). The learning method is an activity 
that takes place simultaneously and has a close relationship. The teaching method is a part of educational activities and the implementation of the basic competency standards in the curriculum. Learning activities smoothly run if there is an interaction between a teacher and students.

The formulation of understanding methods is usually juxtaposed with techniques, which are both interrelated. Islamic educational method is a general procedure in delivering material to achieve educational goals based on certain assumptions about Islam as a supra system. At the same time, Islamic education techniques are concrete steps for an educator to learn in class.

In educational literature, especially in teaching science, there are many teaching methods. The experts rarely discuss the method of educating. The reason is that the teaching method is clearer, more explicit and objective, even universal. Meanwhile, apart from teaching, other educational methods are more subjective, less clear, less explicit, and more artistic than scientific. It is inconceivable to the extent of the development of these methods. There are currently more than 16 methods. These methods are called general methods because they are used for general teaching. Usually, general education methods are referred to as teaching methods (Soetoe, 1982: 28).

\section{Teaching Methods in Islamic Education}

In the process of Islamic education, appropriate education contains values that are in line with the subject matter and functionally can be used to realize the ideal values contained in the goals of Islamic education. There are many educational methods used in the teaching process. It is inseparable from the goals to be achieved, namely shaping students to be better than before.

Islamic education books contain many descriptions of general teaching method that Islamic teachers have used. Al-Syaibany in Hidayat, Syahidin, \& Rizal (2021) stated in his book that the most prominent general methods could be briefly mentioned as follows: inductive, comparison (Qiyāsiah), lecture, dialogue, discussion, circle (halqah), history, listening, reading, dictation (imla'), memorization, comprehension, and visit methods to study.

There is no one teaching method that is the same for all educational purposes, knowledge, subjects, developmental stages, learning stages, maturity stages, intelligence stages, and atmosphere that include learning processes. There is no way to impose certain methods on teachers in both Islamic and general education. Teachers in Islamic education are the creators of their teaching methods. Therefore, it is the teacher's right to choose a method according to the educational goals to achieve (Al-Syaibany in Rianie, 2015).

There are types of methods and ways of teaching both in Islamic and general education: 1) Methods based on the tools and materials used, such as book laboratory methods; 2) Methods based on finding facts, such as the scientific visit, lecture, experiment methods; 3) The method based on the arrangement of subjects, such as psychological preparation and logical compilation methods, following compilation cases 
of developing experience; 4) Methods based on the objectives intended by the teacher, such as the methods of advice, instruction, guidance, practice, enjoyment, appreciation, thought, conclusion, analysis, interpretation, and experiential development; 5) Methods that stand on student objectives, such as problem solving and project methods; 6) Methods based on the reciprocal relationship between students and teachers, such as teaching, guided learning, and freely chosen project methods; 7) Methods based on reciprocal relationships between students with others, such as activity individual, committee, and cooperative activity methods; 8) The method is based on the level of student participation in the educational process, such as the student presentation method, the participation method composed of students, the joint listening method and the student activity method; 9) Methods based on the level of freedom of thought, such as the instruction, drawing conclusions, and the experimental methods; 10) Methods based on the methods used in tests and assessments, such as the oral and written report methods; and 11) Methods based on the external senses, such as the visual, auditory, and psychomotor methods (Hidayat, Syahidin, \& Rizal, 2021).

Abdullah (2005) suggested several educational methods: First, the story and lecture methods, which are a method carried out by conveying the notions of learning materials to students through explanation or oral narrative accompanied by stories about events and historical events from the Qur'an. Second, the discussion method is a learning system carried out through discussion. Third, the question and answer method or dialogue, the learning process through the teacher asking questions, students answering or having a dialogue by exchanging ideas. Fourth, the parable or metaphor method, explaining abstract concepts with concrete meanings, gives a clear picture for students. The parable here is the parable contained in the Qur'an. Fifth, the method of punishment and reward which carried out by giving punishment to students. Punishment is the worst method of all, but under certain conditions, it must be used.

An-Nahlawi in Rianie (2015) suggested an educational methods based on the Qur'an and Hadith methods that can touch feelings, namely: First, conversation (Hiwar) method of Qur'an and Nabawi is an alternative conversation between two or more parties regarding a topic and deliberately directed to a goal desired by the teacher. Second, the Qur'anic and Prophetic Story Method is the presentation of learning materials that display stories contained in the Qur'an and Hadith of the Prophet Muhammad SAW. Third, the Qur'anic proverb (parable) method is the presentation of learning materials by raising the parables in the Qur'an. Fourth, the exemplary method is to provide a good example to students in everyday life. Fifth, the habituation method is to get students to do something since they born. The essence of this habit is repetition, so what students do will be repeated. Sixth, Ibrah and Mau'izah Methods, Ibrah presents learning materials that aim to train students' reasoning power in capturing the hidden meaning of a statement or a psychic condition that conveys humans to the essence of something witnessed, which is faced using reason. While Mau'izah method is the provision of motivation by using the advantages and disadvantages in carrying out actions. Seventh, Targhib and Tarhib Methods. These methods are a presentation of 
learning in the context of the happy afterlife.

Several teaching methods were also proposed by Fikri (2011), which were used in the teaching and learning process at Islamic educational institutions, including 1) The lecture method is a method of delivering subject matter to students by way of direct oral speech that is heard by students, both on a small scale or large amount. 2) The method of discussion in the social life of society, especially in the relationship of educative interactions, humans are often faced with various kinds of life problems, sometimes these problems can be solved individually, but many also need the help of others to solve them. 3) Demonstration method is a teaching method using media or teaching aids to explain a particular concept or subject matter or show students how to do and run a process. 4) Insertion method is a method that presents subject matter by inserting the essence of Islamic religious subject matter in general subject matter, aiming that students not only receive an explanation of general scientific subject matter but also able to see comparisons of studies through the perspective of religious studies. 5) Wrapping method, namely a method that presents religious subject matter intentionally wrapped or covered with other materials, such as through stories or other sciences such as history, covers religious norms through general material. 6) The inquiry method is a teaching method carried out by presenting an event that contains a puzzle or problem to students so that they are encouraged to seek solutions to the problem.

\section{CONCLUSION}

Communicative teaching methods will be effective and fun in the learning process, even though the material being taught is not very interesting. Conversely, the material is quite good because it is delivered less attractively, the material itself is less accessible to students. Therefore, the application of the right method affects the success in the teaching and learning process. Several teaching methods used in Islamic education include: 1) Lecture Method, 2) Discussion Method, 3) Demonstration Method, 4) Insertion Method, 5) Wrapping Method, and 6) Inquiry Method. The method will be used appropriately and correctly if adjusted to the needs, both related to the material, educational goals, atmosphere of the learning environment, and students' psychological condition. Therefore, teachers are required to choose and determine the right method so that the achievement of educational goals can be carried out effectively and efficiently.

\section{REFERENCES}

Abdullah, A. S. (2005). Educational Theory a Quranic Outlook, diterjemahkan Oleh M. Arifin dan Zainuddi, Teori-Teori Pendidikan Berdasarkan Al-Qur'an. Rineka Cipta.

Afzalurrahman. (1980). Islam, Ideologi and the Way of Life. Singapore: Pustaka Nasional.

Ahmad, K. (1958). Prinsip-Prinsip Pendidikan Islam (M. Hashem (ed.); II). Bandung: Kota Kembang.

Al-Abrasyi, A. (1992). Attarbiyatul Islamiyah (I). Beirut: Dar Al-Syamiyah. 
Al-Syaibani, U. M. al-T. (1979). Falsafah Pendidikan Islam (H. Langgulung (ed.)). Jakarta: Bulan Bintang.

Amir, A. R. (2002). Materi Mata Kuliah Pendekatan dalam Pengkajian Islam 2, PPS UIN Alauddin. Ujungpandang: IAIN Alauddin.

Arifin, M. (1994). Ilmu Pendidikan Islam: Suatu Tinjauan Teoritis dan Praktis Berdasarkan Pendekatan Interdisipliner. Jakarta: Radar Jaya Offset.

Daud, M. (2006). Pendidikan Agama Islam (I). Jakarta: Raja Gafindo.

Departemen Agama RI. (1997). Al-Qur'an dan Terjemahnya (XI). Semarang: PT. Toha Putra.

Departemen Pendidikan dan Kebudayaan RI. (1990). Kamus Besar Bahasa Indonesia (III). Jakarta: Balai Pustaka.

Fikri, M. (2011). Konsep Pendidikan Islam: Pendekatan Metode Pengajaran. Journal of Islam Futura, 11(1), 116-128. https://doi.org/10.22373/jiif.v11i1.66.

Hidayat, T., Syahidin, \& Rizal, A. S. (2021). Filsafat Metode Mengajar Omar Mohammad AlToumy Al Syaibany dan Implikasinya dalam Pembelajaran Pendidikan Agama Islam di Sekolah Dasar. Jurnal Pendidikan Dasar Nusantara, 6(2), 94-115. https://doi.org/10.29407/jpdn.v6i2.14002.

Kurniawan, B. (1997). Kamus Ilmiah Populer. Surabaya: Cipta Pelajar.

Mahmud, \& Priatna, T. (2008). Sistem dan Pemikiran Tokoh Pendidikan Islam. Azkia Pustaka Utama.

Muhajir, N. (1998). Metodologi Penelitian Kualitatif. Yogyakarta: Rakesarasin.

Nasution, S. (2001). Asas-Asas Kurikulum (IV). Jakarta: Bumi Aksara.

Rianie, N. (2015). Pendekatan dan Metode Pendidikan Islam: Sebuah Perbandingan dalam Konsep Teori Pendidikan Islam dan Barat. Journal of Management of Education, 1(2), 105-117. https://doi.org/10.18592/moe.v1i2.350.

Salim, A. M. (1999). Metodologi Tafsir Sebuah Rekonstruksi Efistimologis Memanfaatkan Keberadaan Ilmu Tafsir Sebagai Disiplin ilmu, Orasi Pengukuhan Guru Besar. Ujung Pandang: IAIN Alauddin.

Soetoe, S. (1982). Psikologi Pendidikan. Jakarta: Lembaga Penerbit Fakultas Ekonomi UI.

Uhbiyati, N. (2008). Ilmu Pendidikan Islam. Bandung: Pustaka Setia.

Usman, B. (2007). Metododologi Pembelajaran Agama Islam (I). Jakarta: Ciputat Pres. 